\title{
Cytotoxicity of Endodontic Irrigants Containing Calcium Hydroxide and Sodium Lauryl Sulphate on Fibroblasts Derived From Mouse L929 Cell Line
}

\author{
Sérgio Valmor BARBOSA (in memorian) \\ Cristiane Maria Sodré BARROSO \\ Patrícia Alvarez RUIZ
}

Health Sciences Postgraduate Program, University of Brasília, Brasilia, DF, Brazil

\begin{abstract}
The aim of this study was to evaluate the cytotoxicity of root canal irrigating solutions containing calcium hydroxide and sodium lauryl sulphate on fibroblasts derived from L929 cell line. Saturated calcium hydroxide aqueous solution (CH), sodium lauryl sulphate (SLS) and SLS associated with calcium hydroxide (HCT20) were diluted with sterile distilled water at 50\%, 20\%, 10\% and 5\% concentrations. Minimum essential medium (MEM) served as the control group. The cytotoxicity of the solutions was evaluated on L929 mouse fibroblast cell line, at 4 and $24 \mathrm{~h}$ of contact time by the $51 \mathrm{Cr}$ radiotracer method. Data were compared and statistical inferences were made with the chi-square test. In all analysis, significance level was set at 5\%. CH and HCT20 showed toxicity at 50\% concentration, while at concentrations lower than $50 \%$ these solutions showed cell tolerance. SLS was cytotoxic at all concentrations. In conclusion, the association of calcium hydroxide and SLS (HCT20) combines the beneficial properties of these solutions and was not harmful to the fibroblast cell line, seeming to be a suitable endodontic irrigating solution.
\end{abstract}

Key Words: cytotoxicity, calcium hydroxide, sodium lauryl sulphate, endodontic irrigants.

\section{INTRODUCTION}

Dental pulp and periapical tissues are commonly affected by a widely varied microbial flora, including Gram-positive and Gram-negative microorganisms and their metabolite byproducts or toxins. Even after microbial death, components of the cellular wall, such as lipopolysaccharide(LPS), persist for prolonged periods and can cause biological reactions resulting in chronic inflammation (1).

Endodontic therapy requires use of irrigating solutions to eliminate microorganisms, remove debris and neutralize organic compounds. Because of the risk of leakage through the apical foramen, irrigants must be biocompatible and non-irritant to the periapical tissues $(2,3)$. Sodium hypochlorite $(\mathrm{NaOCl})$ is the most commonly used irrigating solution because it has outstanding antibacterial action, bleaches the dentin and dissolves organic material (4-6). It must be used with adequated irrigation and instrumentation technique, since may pass through apical foramen causing periapical damage and disturbing repair inhibiting adherence capacity of macrophages. As drawbacks, the high superficial tension of this chemical irrigant avoids its penetration into the canal system irregularities and its use increases the dentin hydraulic conductivity (2,6-9).

Calcium hydroxide has antimicrobial action, neutralizes microbial organic debris, induces repair with mineralized tissue deposition and hydrolyzes the lipid moiety of LPS $(1,4,10-12)$. It has low solubility in water and high superficial tension, which is lowered with the association to sodium lauryl sulphate (SLS) (13). The toxicity of calcium hydroxide solutions has not yet been clearly elucidated.

The aim of this study was to evaluate in vitro the cytotoxicity of saturated calcium hydroxide solutions, sodium lauryl sulphate and HCT20 (sodium lauryl sulphate associated with calcium hydroxide solution) at $5 \%, 10 \%, 20 \%$ and $50 \%$ concentrations on fibroblasts derived from L929 cell line. 


\section{MATERIAL AND METHODS}

Three potential irrigating solutions were evaluated. Saturated calcium hydroxide aqueous solution composed of $0.2 \mathrm{~g}$ of calcium hydroxide in $100 \mathrm{~mL}$ distilled water, pH 12.2 (Calcium Hydroxide, Sigma, St. Louis, MO, USA), designated as $\mathrm{CH}, 0.125 \%$ sodium lauryl sulphate in distilled water, $\mathrm{pH} 7.8$ (Tergensol-Inodon; Porto Alegre, RS, Brazil), designated as SLS, and $0.16 \mathrm{~g}$ calcium hydroxide plus $0.025 \%$ sodium lauryl sulphate in $100 \mathrm{~mL}$ distilled water, $\mathrm{pH} 11.0$, named HCT20. The solutions were diluted with sterile distilled water at $50 \%$, $20 \%, 10 \%$ and $5 \%$ concentrations. Minimum essential medium (MEM) served as a control group.

Fibroblasts derived from mouse L929 cell line (ATCC L929) were used due to their suitability for cytotoxicity evaluation. The culture medium was minimum MEM with Eagle's salts (Flow Laboratories, McLean, VA, USA) supplemented with $10 \%$ (v/v) fetal bovine serum, with $100 \mathrm{IU} / \mathrm{mL}$ penicillin, $\mu \mathrm{g} / \mathrm{mL}$ of streptomycin, $2 \mathrm{mM} / \mathrm{L}$ glutamine and $2.2 \mathrm{mg} / \mathrm{mL}$ of sodium bicarbonate. Five- to 7-day cultures were used for the experiments. The culture medium was changed every other day, and the day before the experiments. The ${ }^{51} \mathrm{Cr}$ was supplied as sodium chromate in sterile isotonic saline (Dupont NEN, Wilmington, DE, USA). Cell monolayer cultures were labelled by incubation with $1 \mu \mathrm{Ci}$ per $10^{5}$ cells, 20 to $24 \mathrm{~h}$ before the experiments (14). The labelled cells were harvested with $0.125 \%$ trypsin and washed 3 times in $\mathrm{Ca}^{2+}$ free and $\mathrm{Mg}^{2+}$ free phosphate buffered saline (PBS). The cells were resuspended in MEM at a concentration of $4 \times 10^{4}$ cells $/ \mathrm{mL}$.

One milliliter of the test solution was mixed with $1 \mathrm{~mL}$ of labeled cell suspension in multiwell cell

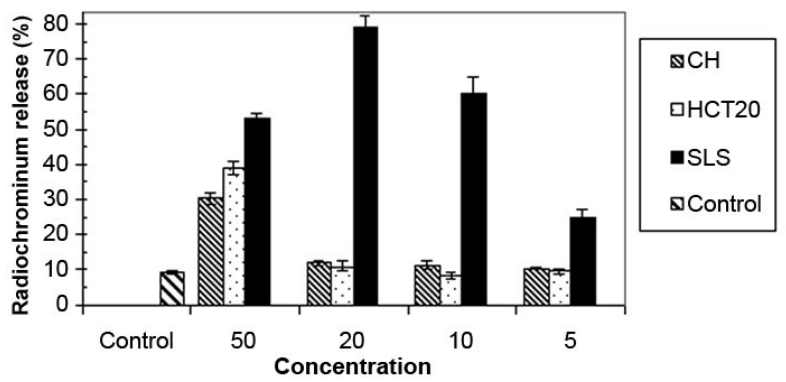

Figure 1. Effects of irrigating solutions on L929 mouse fibroblast cell line in vitro. Release of radiochromium (\%) after $4 \mathrm{~h}$ of exposure. Values are expressed as Mean $\pm \mathrm{SD}(\mathrm{n}=10)$. culture plates (Costar, Cambridge, MA, USA), in such a way that the test concentration of each solution evaluated was $5 \%, 10 \%, 20 \%$ and $50 \%$. Ten samples of each solution were used for each experimental period. In the control wells, the irrigating solution was replaced by MEM. During the dispensing of the cells, cell suspension was randomly distributed into 6 test tubes and used as reference samples. The experimental and control plates were incubated for 4 and $24 \mathrm{~h}$ at $37^{\circ} \mathrm{C}$ in an atmosphere of $5 \% \mathrm{CO}_{2}$ in air and $100 \%$ humidity.

At the end of the exposure period, the $\mathrm{pH}$ of the solutions was obtained by 2 readings and $1 \mathrm{~mL}$ of medium from each well was transferred to test tubes and centrifuged at $500 \mathrm{~g}$ for $8 \mathrm{~min}$. The supernatant $(0.5$ $\mathrm{mL}$ ) was counted for $1 \mathrm{~min}$ in a gamma-particle counter (Gamma 5500; Beckman Instruments, Wakefield, MA, USA). The percentage of ${ }^{51} \mathrm{Cr}$ released from the experimental and control samples was calculated according the equation: ${ }^{51} \mathrm{Cr}$ release in percentage $=\underline{2 \times(\mathrm{T}-\mathrm{b})} \times 100$, R-b

where $\mathrm{T}=$ chromium released in test samples, $\mathrm{b}=$ background radiation and $\mathrm{R}=$ reference sample.

Sample frequencies were compared and statistical inferences were made using the chi-square test at 5\% significance level.

\section{RESULTS}

All solutions showed some level of toxicity. $\mathrm{CH}$ and HCT20 at 50\% concentration presented significant chromium release, being 2-3 times greater than that of the control group. At $20 \%, 10 \%$ and $5 \%$ concentrations, however, these solutions had similar behavior to the control group. SLS showed high toxicity at all evaluated concentrations. The different concentrations of the solutions did not show significant $\mathrm{pH}$ variation. Data are graphically presented in Figures 1 and 2.

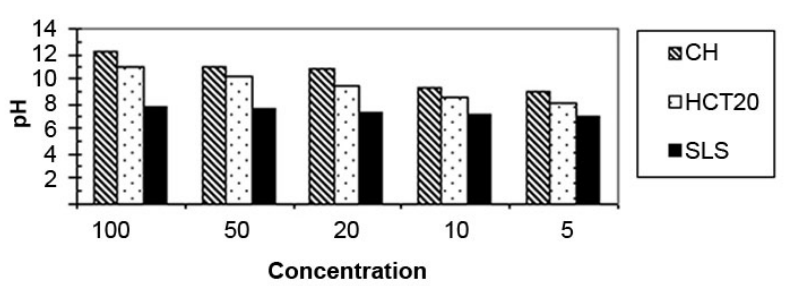

Figure 2. $\mathrm{pH}$ of the irrigating solutions. 


\section{DISCUSSION}

$\mathrm{CH}$ and HCT20 at concentrations below 50\% presented similar results to those of the control group on L929 fibroblasts. These data reveal good biological behavior since MEM is not harmful to cell viability and therefore it is possible that the extrusion of those solutions do not cause damage to the periapical tissues. The $\mathrm{pH}$ of $\mathrm{CH}$ and $\mathrm{HCT} 20$ at $5 \%, 10 \%$ and $20 \%$ concentrations is not viable for the survival of various microorganisms of endodontic infections (Fig. 2) (12,13,15).

At the highest concentration $(50 \%), \mathrm{Ca}(\mathrm{OH})_{2}$ and HCT20 were cytotoxic, which may be related to the superficial caustic action and the enhancement of tissue solubility inherent to calcium hydroxide $(4,16)$. Some authors $(5,17)$ have previously reported that calcium hydroxide can dissolve dental pulp remnants and affect the dental pulp stump, but its reparative action requires a high $\mathrm{pH}$ to occur $(12,16)$.

SLS properties, such as low superficial tension and lubricant ability, certainly help the flushing action and cleaning of the root canal system (18). Though, it does not have antimicrobial action (13) and has some level of cytotoxicity, since it solubilizes proteins (19). In the present study, SLS was cytotoxic at all concentrations, and thus this solution does not fulfill the requirements for an acceptable endodontic irrigant. However, SLS can increase LPS disaggregation (19) and inhibit bacterial coaggregation (20). In combination with calcium hydroxide, it may be a viable irrigating solution, since calcium hydroxide has antimicrobial action, detoxifies the bacterial LPS and is tolerated by the tissues $(1,10,11)$. The association of these substances does not seem to have drawbacks to endodontic therapy.

The evaluation of irrigating solutions using

${ }^{51} \mathrm{Cr}$ radiotracer assay is an accurate and well known method because it allows the contact liquid/cells (14). In vivo, differences may be understood as suitable and support the use of the irrigating solution because the contact time during an endodontic treatment is lesser. In this study the evaluation performed done for $4 \mathrm{~h}$ to warranty accurate readings.

Apical extrusion of debris and solutions during root canal instrumentation is an important aspect to be considered resulting in inflammation or flare-up $(2,3)$. Therefore, it is recommended that endodontic irrigants are biocompatible, present antimicrobial activity and stimulate or do not jeopardize the periapical repair (13).
Comparison of other irrigants and calcium hydroxide solutions, with or without SLS, indicates no better results considering the combination of effective antiseptic action and low toxicity $(9,10)$. Due to its biological properties, calcium hydroxide solutions can extrude to the periapical region without causing tissue damage. In conclusion, the association of calcium hydroxide and SLS (HCT20) combines the beneficial properties of these solutions and was not harmful to the fibroblast cell line, seeming to be a suitable endodontic irrigating solution.

\section{RESUMO}

O objetivo desta pesquisa foi avaliar a citotoxicidade de soluções irrigadoras de canais radiculares contendo hidróxido de cálcio e lauril sulfato de sódio em linhagem de fibroblastos L929. Solução aquosa saturada de hidróxido de cálcio, lauril sulfato de sódio e HCT20 (lauril sulfato de sódio e hidróxido de cálcio) foram diluídos em água destilada em concentrações de 50\%, 20\%, 10\% e $5 \%$. O grupo controle foi representado por meio de cultura de células (MEM - minimum essential medium). A citotoxicidade das soluções sobre os fibroblastos foi avaliada em 4 e $24 \mathrm{~h}$ de contato, pelo método do cromo radioativo. Os resultados foram analisados estatisticamente pelo teste do qui-quadrado. Em todas as análises, o intervalo de confiança referente às médias entre os grupos foi estabelecido em $95 \%$. As soluções saturadas de hidróxido de cálcio e o HCT20 apresentaram toxicidade nas concentrações de $50 \%$. O lauril sulfato de sódio foi tóxico em todas as concentrações. As soluções de hidróxido de cálcio em concentrações menores que $50 \%$ apresentaram tolerância celular, assim como combinadas ao lauril sulfato de sódio. Tal comportamento não foi observado na solução pura de lauril sulfato de sódio em todas as concentrações.

\section{REFERENCES}

1. Silva L, Nelson-Filho P, Leonardo MR, Rossi MA, Pansani RA. Effect of calcium hydroxide on bacterial endotoxin in vivo. J Endod 2002;28:94-98.

2. Ferraz CC, Gomes NV, Gomes BP, Zaia AA, Teixeira FB, SouzaFilho FJ. Apical extrusion of debris and irrigants using two hand and three engine-driven instrumentation techniques. Int Endod J 2001;34:354-358.

3. Lambrianidis T, Tosounidou E, Tzoanopoulou M. The effect of maintaining apical patency on periapical extrusion. J Endod 2001;27:696-698.

4. Hasselgren G, Olsson B, Cvek M. Effects of calcium hydroxide and sodium hypochlorite on the dissolution of necrotic porcine muscle tissue. J Endod 1988;14:125-127.

5. Andersen M, Lund A, Andreasen JO, Andreasen FM. In vitro solubility of human pulp tissue in calcium hydroxide and sodium hypochlorite. Endod Dent Traumatol 1992;8:104-108.

6. Estrela C, Estrela CRA, Barbin EL, Spanó JCE, Marchesan MA, Pécora JD. Mechanism of action of sodium hypochlorite. Braz Dent J 2002;13:113-117.

7. Barbosa SV, Safavi KE, Spangberg SW. Influence of sodium hypochlorite on the permeability and structure of cervical human 
dentine. Int Endod J 1994;27:309-312.

8. Jiménez-Rubio A, Segura JJ, Llmas R, Jiménez-Planas A, Guerrero JM, Calvo JR. In vitro study of the effect of sodium hypochlorite and glutaraldehyde on substrate adherence capacity of macrophages. J Endod 1997;23:562-564.

9. Chang YC, Huang FM, Tai KW, Chou MY. The effect of sodium hypochlorite and chlorhexidine on cultured human periodontal ligament cells. Oral Surg Oral Med Oral Pathol Oral Radiol Endod 2001;92:446-450.

10. Sathorn C, Parashos P, Messer H. Antimicrobial efficacy of calcium hydroxide intracanal dressing: a systematic review and meta-analysis. Int Endod J 2007;40:2-10.

11. Safavi KE, Nichols FC. Effect of calcium hydroxide on bacterial lipopolysaccharide. J Endod 1993;19:76-78.

12. Zmener $\mathrm{O}$, Pameijer $\mathrm{CH}$, Banegas $\mathrm{G}$. An in vitro study of the $\mathrm{pH}$ of three calcium hydroxide dressing materials. Dent Traumatol 2007;23:21-25.

13. Barbosa SV, Spangberg LSW, Almeida D. Low surface tension calcium hydroxide solution is an effective antiseptic. Int Endod J 1994;27:6-10.

14. Spangberg L. Kinetic and quantitative evaluation of material cyto- toxicity in vitro. Oral Surg Oral Med Oral Pathol 1973;35:389-401.

15. Behnen MJ, West LA, Liewehr FR, Buxton TB, McPerson JC. Antimicrobial activity of several calcium hydroxide preparations in root canal dentin. J Endod 2001;27:765-767.

16. Dominguez MS, Witherspoon DE, Gutmann JL, Opperman LA. Histological and scanning electron microscopy assessment of various vital pulp-therapy materials. J Endod 2003;29:324-233.

17. Morgan RW, Carnes DL, Montgomery S. The solvent effects of calcium hydroxide irrigating solution on bovine pulp tissue. $\mathrm{J}$ Endod 1991;17:165-168.

18. Lehman J, Bell WA, Gerstein H. Sodium lauryl sulfate as an endodontic irrigant. J Endod 1981;7:381-384.

19. Harewood K, Wolf JS. A rapid electrophoretic procedure for the detection of SDS-released Oncorna-viral RNA using polyacrylamide-agarose gels. Anal Biochem 1973;55:573-581.

20. McIntire FC, Crosby LK, Vatter AE. Inhibitors of coaggregation between Actinomyces viscosus T14V and Streptococcus sanguis 34: $\beta$-Galactosides, related sugars, and anionic amphypathic compounds. Infect Immun 1982;36:371-378.

Accepted February 10, 2009 